\title{
Effects of starvation on swimming performance and body condition of pre-settlement Sparus aurata larvae
}

\author{
Ana M. Faria ${ }^{1,2}$, Maria A. Chícharo ${ }^{2}$, Emanuel J. Gonçalves ${ }^{1, *}$ \\ ${ }^{1}$ Eco-Ethology Research Unit, Instituto Superior de Psicologia Aplicada, R. Jardim do Tabaco 34, 1149-041 Lisbon, Portugal \\ ${ }^{2}$ Centre of Marine Sciences, CCMAR, University of Algarve, Campus de Gambelas, 8005-117 Faro, Portugal
}

\begin{abstract}
Body condition in larval fishes is an important determinant of survival in the natural environment. However, few studies correlate body condition with behavioural traits critical for survival, such as swimming performance. In the present study, we compared normally fed larvae of gilthead seabream Sparus aurata Linnaeus, 1758, at various intervals post-hatch with larvae which were starved for 1 to $3 \mathrm{~d}$ (for $U_{\text {crit }}$ ) or $2 \mathrm{~d}$ (for swimming endurance). Feeding treatment (fed and or unfed) had no effect on the relationship between $U_{\text {crit }}$ and larval size. However, in the endurance experiment, fed individuals swam twice as far as unfed larvae $(19.7 \mathrm{~km}$ for fed larvae and $9.5 \mathrm{~km}$ for unfed larvae). The RNA/DNA ratio was higher in fed larvae in the $U_{\text {crit }}$ experiment, but significant effects were only detectable after a $3 \mathrm{~d}$ period of starvation. Fulton's condition factor was significantly higher in fed larvae in the endurance trial, which suggests that growth (in weight) of starved larvae was affected by long-term swimming. Taken together, these results suggest that foraging and orientation behaviours (activities in which critical speeds might be involved) are not affected by reduced feeding over a few days, but that sub-lethal effects of starvation may affect dispersal potential (for which endurance swimming is critical) and therefore compromise subsequent recruitment to the adult population.
\end{abstract}

KEY WORDS: Gilthead seabream - Swimming performance $\cdot$ Nutritional condition $\cdot$ Sub-lethal effects $\cdot$ RNA/DNA ratio $\cdot$ Fulton's condition factor

\section{INTRODUCTION}

Early life stages of marine fishes typically experience high rates of mortality, with strong implications on future recruitment. Predation and starvation are considered to be the 2 major causes of mortality in larval fishes (Miller et al. 1988, Bailey \& Houde 1989). These 2 factors can act together to increase mortality rates, as starved or underfed larvae may be more susceptible to predation (Neilson et al. 1986). Some evidence suggests that general activity or vertical migratory activity declines in starved larvae of several species (Laurence 1972, Blaxter \& Ehrlich 1974). Moreover, starvation leads to decreased growth rates (Ehrlich et al. 1976,
Yin \& Blaxter 1986), slower development (Kamler et al. 1990), and changes in behaviour for energy-saving purposes (Munk 1995, Ross et al. 1996, Chick \& Van den Avyle 2000, Skajaa et al. 2004). Thus it is expected that larvae with low nutritional condition will be smaller and less developed in sensory and locomotory capacities than well-fed larvae.

Despite several studies indicating that good body condition at the larval stage can be correlated with higher growth rate in larvae and enhanced recruitment or juvenile survival under natural conditions (Searcy \& Sponaugle 2001, Bergenius et al. 2002, McCormick \& Hoey 2004, Sponaugle et al. 2006), few attempts have been made to correlate larval condition 
with any behavioural function critical for larval survival, such as swimming behaviour (e.g. Laurence 1972, Yin \& Blaxter 1987, Chick \& Van den Avyle 2000). Swimming is one of the most important behaviours in larval fish, determining to a large extent the success of predator avoidance, prey capture and dispersal potential (Reidy et al. 2000, Armsworth 2001, Plaut 2001, Fisher \& Wilson 2004). It has been shown that larvae in good condition possess better swimming abilities and responsiveness to predators than larvae in poor condition (Chick \& Van den Avyle 2000, GrorudColvert \& Sponaugle 2006).

Larval condition may be estimated by a variety of morphometric, biochemical, histological, or otolith growth indices. Fulton's condition factor $K$ is a morphometric index commonly used as an indicator of an individual's general well-being and is based on the assumption that heavier fish for a given length are in better condition (Ricker 1975, Suthers 1998). The RNA/ DNA ratio is a widely used biochemical index of nutritional condition and recent growth of larval fishes (e.g. Clemmesen et al. 1997, Buckley et al. 1999, Esteves et al. 2000, Caldarone et al. 2003) and it reflects variations in protein synthesis rates (recent growth), as RNA concentration varies both with food intake and protein requirement, while DNA somatic content remains relatively constant (Bulow 1970).

In the present study, we examined the influence of starvation on the condition (measured through the RNA/DNA ratio and Fulton's condition factor) and swimming behaviour of gilthead seabream larvae Sparus aurata. We hypothesised that starved larvae would perform more poorly than fed larvae, using swimming abilities as a measure of behavioural performance. Two of the most common measures of swimming ability (critical speed and swimming endurance) were measured in larvae that had either been fed ad libitum or starved for 1, 2, or $3 \mathrm{~d}$. Pre-settlement stages were chosen because this phase is often characterised by very high mortality rates (Almany \& Webster 2005, Leis 2006), with obvious implications for the subsequent survival of and recruitment to the adult population (Searcy \& Sponaugle 2001, Grorud-Colvert \& Sponaugle 2006).

\begin{tabular}{|c|c|c|c|c|c|c|}
\hline & \multicolumn{6}{|c|}{ Days post-hatch } \\
\hline & 25 & 30 & 35 & 36 & 37 & 50 \\
\hline$U_{\text {crit }}$ & $\leadsto \underset{24 h}{\approx}$ & $\propto \underset{24 h}{\approx}$ & $\leadsto \underset{24 h}{\propto}$ & $\underset{48 h}{\Theta}$ & $\underset{72 h}{\propto}$ & \\
\hline Endurance & & & & & & $\leadsto \underset{48 h}{O}$ \\
\hline
\end{tabular}

Fig. 1. Sparus aurata. Behavioural tests conducted on $S$. aurata larvae of different ages. Black fish represent larvae fed ad libitum; white fish represent unfed larvae. The hours noted below the white fish indicate the duration of the starvation period. $U_{\text {crit }}$ critical swimming speed

\section{MATERIALS AND METHODS}

Larvae. Sparus aurata Linnaeus, 1758 larvae were obtained from the fish hatchery TIMAR (Algarve, Portugal), at $22 \mathrm{~d}$ post-hatch (dph) and were maintained in 201 aquaria, with constant slight aeration and a photoperiod of $13 \mathrm{~h}$ light:11 h dark. Larvae were raised in a semi-closed circuit of filtered natural seawater originating from the nearby coast. Salinity was kept constant at 37 , and temperature ranged from 20.6 to $22.6^{\circ} \mathrm{C}$.

Larvae were randomly distributed in 2 rearing aquaria: one aquarium with larvae fed ad libitum with Artemia sp. nauplii and the other aquarium with larvae deprived of food for a minimum of $24 \mathrm{~h}$ before experimental tests. The rearing aquaria were placed next to each other, with similar initial larval densities and the same light conditions and water quality, to minimise possible tank effects. Mortality did not differ between tanks.

Two behavioural tests were performed in order to evaluate the influence of feeding treatment on swimming performance: critical swimming speed ( $\left.U_{\text {crit }}\right)$ and swimming endurance. For each experiment, fed and unfed larvae were tested (see Fig. 1). $U_{\text {crit }}$ of fed and unfed ( $24 \mathrm{~h}$ of food deprivation) larvae was measured at 25, 30 and $35 \mathrm{dph}$. After perceiving that $U_{\text {crit }}$ was not affected by a $24 \mathrm{~h}$ period of food deprivation, larvae were tested after starving for $48 \mathrm{~h}$ (36 dph) and $72 \mathrm{~h}$ (37 dph). $U_{\text {crit }}$ was not measured on larvae older than $37 \mathrm{dph}$, because these were already post-flexion larvae, and, by this time, larvae had achieved the maximum flow speed of the swimming chamber $\left(20 \mathrm{~cm} \mathrm{~s}^{-1}\right)$. Swimming endurance was measured on late-stage (50 dph) fed and unfed (48 h of food deprivation) larvae, since endurance experiments measure long-term swimming performance and provide data directly relevant to larval fish dispersal, which, in turn, becomes more important close to the settlement stage. Starvation in the experimental tank was thus sequential, and larvae were tested after each starvation episode. Space, time and logistic constraints prevented us from using an approach whereby all conditions were repeated once in each test to evaluate effects throughout ontogeny. Nevertheless, in spite of possible carry-on effects of each starvation period on the following ones, larvae in the wild will also probably face periods of starvation interspersed with periods of food abundance. Moreover, there were no significant differences in mortality rates or in the relationship between condition (both for RNA/DNA ratio and Fulton's $K$ ) and size between treatments. Therefore, a word of caution is needed when interpreting the results of ontogenetic effects. 
For each experiment, 8 to 12 larvae were tested. After the experiment, larvae were put in liquid nitrogen and stored at $-80^{\circ} \mathrm{C}$ for subsequent RNA/DNA analysis. The larvae were freeze dried and weighed on an ultra-balance with a precision of $1 \mu \mathrm{g}$ (Mettler Toledo MX5) before the biochemical analysis.

Critical swimming speed. $U_{\text {crit }}\left(\mathrm{cm} \mathrm{s}^{-1}\right)$ was measured using a swimming chamber, following the protocols of Stobutzki \& Bellwood $(1994,1997)$. The chamber was made of clear Perspex with 6 parallel swimming lanes, each $30 \mathrm{~mm}$ wide, $50 \mathrm{~mm}$ high and $180 \mathrm{~mm}$ long. A removable lid allowed introduction and removal of fish from the lanes. A strip of black tape on the top of the lid provided fish with a visual reference to maintain position in the flow, and a mesh screen was placed at the upstream and downstream ends of each lane to retain larvae. A section of flow straighteners, $40 \mathrm{~mm}$ long, was placed at the upstream end of each lane to minimise turbulence. Previous work demonstrated that, at the typical $U_{\text {crit, }}$ water velocity was not significantly different between the centre of the lane and $5 \mathrm{~mm}$ from the wall (Stobutzki \& Bellwood 1997, Stobutzki 1998, Fisher et al. 2000). Experimental observations also confirmed that larvae did not show a depth preference in the chamber. The maximum flow speed was $20 \mathrm{~cm} \mathrm{~s}^{-1}$. For details on the swimming chamber characteristics see Faria et al. (2009).

One hour after feeding, larvae were carefully removed from the rearing tank using a small container and were placed individually in large Petri dishes and left undisturbed for $1 \mathrm{~h}$ to allow recovery from handling (Fuiman \& Ottey 1993). After this period, larvae were transferred to the swimming chamber, 1 in each lane, and allowed to acclimate for $5 \mathrm{~min}$ at a flow speed of $1 \mathrm{~cm} \mathrm{~s}^{-1}$. If any behavioural symptoms of stress, such as lying on the bottom or clinging to the sides, were observed after this acclimation period, the individual was removed and replaced by another fish. Water temperatures in the chamber over the study period varied from 20.5 to $23^{\circ} \mathrm{C}$. To measure $U_{\text {crit, }}$ water velocity was increased by approximately $1.2 \mathrm{~cm} \mathrm{~s}^{-1}$ every $2 \mathrm{~min}$ until the larva was unable to swim against the current for 2 min. Calculation of $U_{\text {crit }}$ followed Brett (1964) such that:

$$
U_{\text {crit }}=U+\left(t / t_{i} \times U_{i}\right)
$$

where $U$ is the speed of the penultimate increment, $U_{i}$ is the velocity increment, $t$ is the time swum in the final velocity increment and $t_{i}$ is the time interval for each velocity increment ( $2 \mathrm{~min}$ ). After the test, fish were immediately put in liquid nitrogen for condition analysis.

Swimming endurance. Swimming endurance was measured by swimming larvae at a single speed until exhaustion. The speed of $12 \mathrm{~cm} \mathrm{~s}^{-1}$ (approximately $50 \%$ of the maximum $U_{\text {crit }}$ ) was chosen as a reference. Dur- ing daylight hours, larvae were constantly observed, and the exact time to fatigue was recorded. At night, larvae were observed every $6 \mathrm{~h}$, and the time to fatigue was calculated as the midpoint between when the larva was last seen swimming and when it was found no longer swimming. Only 1 larva stopped swimming during the night period. The swimming duration was converted in distance swum $(\mathrm{km})$ using the flow speed. The values are therefore given as kilometres swum.

Condition indices. RNA and DNA were measured with the microplate fluorescent assay (MFA) of Wagner et al. (1998). The MFA assay is a modification of the sequential fluorometric method of Bentle et al. (1981), in which DNA and RNA in a single sample are determined sequentially by the addition of DNase and RNase, using ethidium bromide (EB) as a fluorescent dye (see Caldarone et al. 2001 for details). Wagner et al. (1998) modified the sequential fluorometric method of the MFA with 96-well microtiter plates by adopting a sarcosyl extraction technique and eliminating the DNase step. The larvae were individually homogenised by sonication (3 pulses 50 A during $1 \mathrm{~min}$ ) with cold sarcosyl extraction buffer. The volume of extraction buffer was $500 \mu \mathrm{l}(0.5 \%)$. The samples were then shaken for $1 \mathrm{~h}$ at room temperature on a vortex mixer equipped with a multiple-vial head. Next, they were centrifuged $(12000 \times g)$ for 15 min to separate insoluble larvae remains. The samples were subsequently diluted 1:10 with Tris buffer to reduce the sarcosyl concentration to $0.05 \%$. In each run, duplicates of $50 \mu \mathrm{l}$ aliquots of the samples' supernatants, in addition to duplicates of $0,0.6,1.1,1.7$, and $2.3 \mu \mathrm{g} \mathrm{ml}^{-1}$ of DNA standard solutions ( $\lambda$-phagus, $0.25 \mu \mathrm{g} \mathrm{ul}^{-1}$ from Roche), $16 \mathrm{~s}$ to $23 \mathrm{~s}$ Escherichia coli RNA ( $4 \mu \mathrm{g} \mu^{-1}$ from Roche) and $0,3.6,7.3,10.9$ and $14.6 \mu \mathrm{g} \mathrm{m}^{-1}$ of RNA standard solutions (16s to $23 \mathrm{~s}$ E. coli, $4 \mu \mathrm{g} \mathrm{ll}^{-1}$ from Roche) were transferred to 96 -well microplates (type nuclon black round bottom). The average slope ratio of DNA and RNA (slope of DNA standard curve/slope of RNA standard curve) was $5.5 \pm 0.8$; this ratio can be used to compare RNA/DNA ratio results determined by other protocols (Caldarone et al. 2006). EB solution (30 $\mu \mathrm{l})$ was added to each well, and the plates were shaken gently at room temperature for $15 \mathrm{~min}$. The EB fluorescence was then scanned on a microplate reader (Biotek synergy HT Model SIAFRTD) with $360 \mathrm{~nm}$ (excitation) and $590 \mathrm{~nm}$ (emission) (first scan: total fluorescence of RNA + DNA). Following the first scan, RNase solution (30 $\mu \mathrm{l}, 0.12 \mu \mathrm{g} \mathrm{ml}^{-1}$ ) was added to each well, and the concentration of DNA was calculated directly from the standard curve. The concentration of RNA was determined indirectly by subtraction of DNA fluorescence (second scan) from total fluorescence (first scan).

Fulton's condition factor was directly determined from morphometric data using the formula: 


$$
K=100 W_{\mathrm{t}} / L^{3}
$$

where $\mathrm{W}_{\mathrm{t}}$ is total wet weight $(\mathrm{mg})$, and $L$ is standard length (mm) (Ricker 1975). For simplicity, it is hereafter referred to as Fulton's $K$.

Standard length (SL) was measured to the nearest $0.01 \mathrm{~mm}$, using Image J software (v. 1.38). Before each photograph was taken, a transparent acetate sheet marked with a millimetre grid was photographed and used as a reference for each measurement in the image analysis software.

Data analysis. Linear regression analyses were used to determine relationships between swimming performance ( $U_{\text {crit }}$ and endurance) and size (SL) for each feeding treatment. Normality was tested using the Kolmogorov-Smirnov statistic, and plots of residuals and predicted values were examined. Only the variables $U_{\text {crit }}$ and SL had a normal distribution; endurance swimming was not normalised by any transformation, and therefore non-parametric tests were applied (Zar 1999).

Only the relationship of $U_{\text {crit }}$ with size provided a linear relationship. In this sense, to determine whether the slopes of the regressions of $U_{\text {crit }}$ on size differed among the 2 feeding treatments, an analysis of covariance (ANCOVA) was performed with $U_{\text {crit }}$ as the dependent variable, feeding treatment as the fixed factor and size (SL) as the co-variate. Data on endurance were analysed by comparing the mean time swum for fed and unfed fish using a Mann-Whitney test.

The relationships between condition (RNA/DNA ratio and Fulton's $K$ ) and SL were examined in both feeding treatments using a Spearman correlation test for non-normally distributed data (Zar 1999). The same statistical test was used to determine whether condition indices could be correlated to the tested swimming measures. To investigate the effect of the duration of the starvation period $(24,48$ and $72 \mathrm{~h})$ on the condition indices, a Kruskal-Wallis test was applied. To examine whether condition indices varied between the 2 feeding treatments, a Mann-Whitney test was applied.

All statistical tests were conducted using STATISTICA (v. 6.0).

\section{RESULTS}

A total of 142 Sparus aurata larvae were tested in the swimming experiments, 81 of which belonged to the unfed group and 61 to the fed group. Larvae from both groups showed a significant and constant growth in standard length up to the end of the experiments (unfed: $F_{1,78}=163.4, \mathrm{p}<0.0001$; fed: $F_{1,55}=161.4, \mathrm{p}<0.0001$; Fig. 2). Overall, no significant effects of starvation on growth (length) were detected $\left(F_{1,134}=3.87, \mathrm{p}<0.05\right)$.

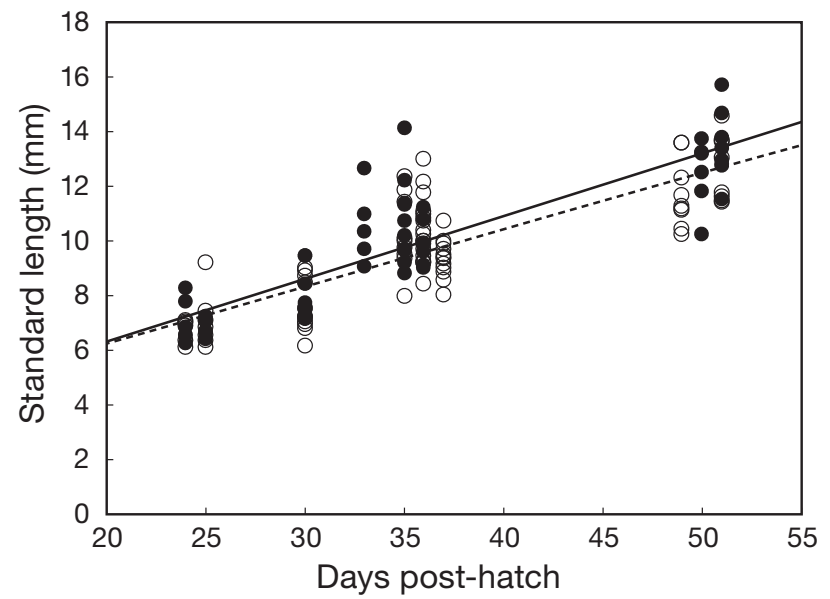

Fig. 2. Sparus aurata. Changes in standard length with age (days post-hatch) of fed (filled circles, solid line: $y=1.72+0.23 x$, $\mathrm{R}^{2}=0.75$ ) and unfed (open circles, dashed line: $y=2.09+0.21 x$, $\mathrm{R}^{2}=0.68$ ) larvae of $S$. aurata. Each symbol represents results for an individual larva

\section{Effect of feeding treatment on swimming performance}

A total of 48 unfed larvae and 30 fed larvae were tested for critical swimming speed. $U_{\text {crit }}$ ranged from 3.0 to $19.3 \mathrm{~cm} \mathrm{~s}^{-1}$, corresponding to 4.5 to 20.9 body lengths (bl) $\mathrm{s}^{-1}$, for the group of fed larvae, over the size range of 6.2 to $14.1 \mathrm{~mm}$ (SL). As expected, $U_{\text {crit }}$ increased significantly with length $\left(F_{1,28}=23.8, \mathrm{p}<\right.$ 0.0001 ; Fig. 3). When analysing differences in swimming performance of unfed larvae tested after different periods of starvation $(24,48$ and $72 \mathrm{~h})$, ANCOVA revealed no differences in the $U_{\text {crit }}$ and length relationship $\left(F_{2,44}=0.07, \mathrm{p}=0.93\right)$. Therefore, these larvae

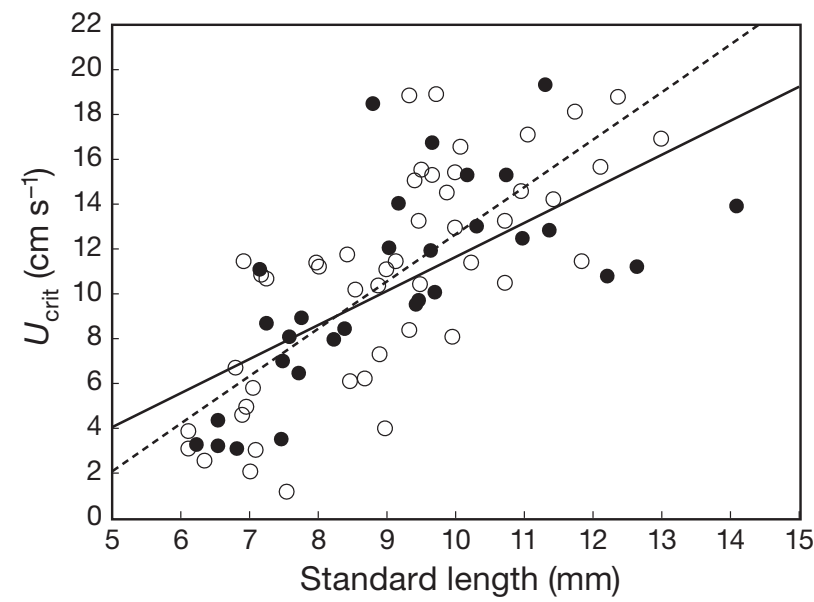

Fig. 3. Sparus aurata. Ontogenetic trend for critical swimming speed $\left(U_{\text {crit }}\right)$ of fed (filled circles, solid line: $y=1.52 x-3.54$, $\mathrm{R}^{2}=0.46$ ) and unfed (open circles, dashed line: $y=2.12 x-$ $8.51, R^{2}=0.56$ ) larvae of $S$. aurata. Each symbol represents results for an individual larva 
were treated as a single unfed group. $U_{\text {crit }}$ of the unfed group revealed a significant relationship with length $\left(F_{1,46}=58.5, \mathrm{p}<0.0001\right.$; Fig. 3), ranging from 1.1 to $18.9 \mathrm{~cm} \mathrm{~s}^{-1}$ (1.5 to $20.2 \mathrm{bl} \mathrm{s}^{-1}$ ) over the size range of from 6.1 to $12.9 \mathrm{~mm}$ (SL). In both feeding treatments, there was large variation in performance among individuals, at any size (Fig. 3).

There was no difference between the slopes of the regressions of $U_{\text {crit }}$ on the size of fed and unfed larvae (ANCOVA: $F_{1,75}=0.39, \mathrm{p}=0.53$ ), indicating that $U_{\text {crit }}$ did not differ between feeding treatments.

To test endurance 10 fed and 10 unfed larvae were stimulated to swim at a constant speed of approximately $12 \mathrm{~cm} \mathrm{~s}^{-1}$. The fed group swam for a significantly longer period than the unfed group $(t=-5.16$, $\mathrm{df}=18, \mathrm{p}<0.0001$ ), with fed larvae swimming about twice as long as unfed larvae (mean $\pm \mathrm{SD}$ : swimming duration of fed larvae $=42.2 \pm 11.1 \mathrm{~h}$; swimming duration of unfed larvae $=20.4 \pm 7.4 \mathrm{~h}$ ). Fed fish swam an equivalent mean distance of $19.7 \mathrm{~km}$ (range: 10.3 to 23.9), whereas unfed fish swam an equivalent mean distance of $9.5 \mathrm{~km}$ (range: 4.4 to 14.1) (Fig. 4).

\section{Effect of feeding treatment on body condition}

RNA/DNA ratio and Fulton's $K$ were both highly correlated with length (SL) and age, in both feeding treatments (Table 1). Both condition indices were significantly higher for fed larvae than for unfed larvae (RNA/DNA ratio: Mann-Whitney, $U=1418.0, \mathrm{p}<$ 0.001; Fulton's K: Mann-Whitney, $U=4612.0, \mathrm{p}=0.003$; Table 2). When analysing all data pooled together, the RNA/DNA ratio was the only condition measure affected by the duration of the starvation period (Kruskal-Wallis, $H[2, \mathrm{~N}=80]=8.27, \mathrm{p}=0.016$ ), but only after $3 \mathrm{~d}$ of food deprivation.

When investigating whether the condition indices were correlated with the type of swimming measured ( $U_{\text {crit }}$ or endurance), in each feeding treatment, the

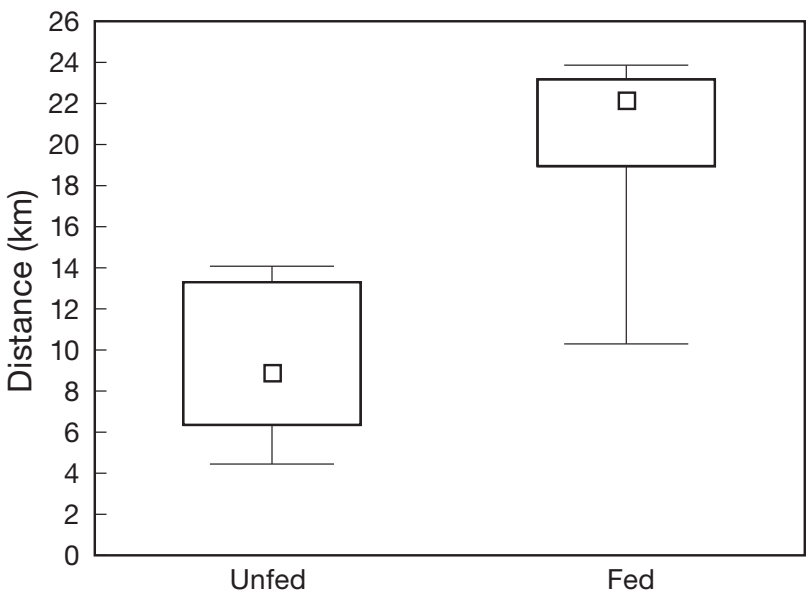

Fig. 4. Sparus aurata. Comparison of distance travelled (km) between fed and unfed larvae of $S$. aurata in endurance tests. Small squares represent the median, box values represent 25 to $75 \%$ percentiles and whiskers represent minimum and maximum distances swum by the larvae (see 'Results' for statistical results)

results showed that the RNA/DNA ratio is positively correlated with $U_{\text {crit }}$ in both fed and unfed larvae, and Fulton's $K$ is highly correlated with endurance in fed larvae (Table 3).

Table 1. Sparus aurata. Spearman rank correlation coefficients between length (standard length) and age (days post-hatch) and the 2 measures of condition (RNA/DNA, Fulton's $K$ ) in fed and unfed larvae. ${ }^{*} \mathrm{p}<0.005 ;{ }^{* *} \mathrm{p}<0.05$

\begin{tabular}{|lll|}
\hline & Length & Age \\
\hline Fed & & \\
RNA/DNA & $0.53^{*}$ & $0.40^{*}$ \\
Fulton's $K$ & $0.31^{* *}$ & $0.35^{* *}$ \\
Unfed & & \\
RNA/DNA & $0.50^{*}$ & $0.32^{*}$ \\
Fulton's $K$ & $0.31^{* *}$ & $0.35^{*}$ \\
\hline
\end{tabular}

Table 2. Sparus aurata. Nucleic acid content and Fulton's $K$ factor of analysed larvae for the fed and unfed groups in the $U_{\text {crit }}$ and endurance experiments (average \pm standard deviation). N: number of larvae; SL: standard length; DW: dry weight

\begin{tabular}{|c|c|c|c|c|c|c|c|c|c|}
\hline & $\mathrm{N}$ & $\begin{array}{c}\mathrm{SL} \\
(\mathrm{mm})\end{array}$ & $\begin{array}{l}\text { Weight } \\
(\mathrm{mg})\end{array}$ & $\begin{array}{l}\text { RNA larva }^{-1} \\
(\mu g)\end{array}$ & $\begin{array}{l}\text { RNA mg }{ }^{-1} \text { DW } \\
(\mu g)\end{array}$ & $\begin{array}{c}\text { DNA larva }{ }^{-1} \\
(\mu g)\end{array}$ & $\begin{array}{c}\text { DNA mg }{ }^{-1} \text { DW } \\
(\mu g)\end{array}$ & RNA/DNA & Fulton's $K$ \\
\hline \multicolumn{10}{|l|}{$U_{\text {crit }}$} \\
\hline Unfed & 48 & $9.07 \pm 1.75$ & $1.82 \pm 1.50$ & $134.95 \pm 188.50$ & $82.55 \pm 95.39$ & $75.03 \pm 89.30$ & $49.93 \pm 46.96$ & $1.89 \pm 1.10$ & $0.22 \pm 0.16$ \\
\hline Fed & 30 & $9.13 \pm 1.98$ & $2.31 \pm 1.97$ & $471.39 \pm 934.48$ & $160.78 \pm 175.17$ & $122.03 \pm 209.93$ & $46.97 \pm 47.12$ & $3.31 \pm 1.59$ & $0.28 \pm 0.24$ \\
\hline \multicolumn{10}{|c|}{ Endurance } \\
\hline Unfed & 9 & $11.70 \pm 1.22$ & $3.67 \pm 1.82$ & $248.13 \pm 171.81$ & $74.54 \pm 44.78$ & $383.04 \pm 605.97$ & $142.89 \pm 281.14$ & $2.64 \pm 2.34$ & $0.21 \pm 0.05$ \\
\hline Fed & 6 & $12.44 \pm 1.28$ & $5.88 \pm 1.74$ & $717.93 \pm 670.43$ & $114.28 \pm 89.87$ & $335.16 \pm 416.92$ & $52.22 \pm 59.28$ & $2.66 \pm 1.69$ & $0.30 \pm 0.05$ \\
\hline
\end{tabular}


Table 3. Sparus aurata. Spearman rank correlation coefficients between swimming type ( $U_{\text {crit }}$ and endurance) and the 2 measures of condition (RNA/DNA, Fulton's $K$ ) in fed and unfed larvae. ${ }^{*} \mathrm{p}<0.005 ;{ }^{* *} \mathrm{p}<0.05$

\begin{tabular}{|llc|}
\hline & $U_{\text {crit }}$ & Endurance \\
\hline Fed & & \\
RNA/DNA & $0.43^{* *}$ & -0.12 \\
Fulton's $K$ & 0.03 & $0.98^{*}$ \\
Unfed & & \\
RNA/DNA & $0.47^{*}$ & 0.31 \\
Fulton's $K$ & 0.11 & -0.22 \\
\hline
\end{tabular}

\section{DISCUSSION}

Sparus aurata larvae became more competent swimmers with size. $U_{\text {crit }}$ increased throughout ontogeny, for both fed and unfed larvae. Nevertheless, variation at any size was large, and size itself only explained 46 and $56 \%$ of the variation in critical swimming performance for fed and unfed groups, respectively. Similar results have been documented in other experimental works with other species (e.g. Clark et al. 2005, Faria et al. 2009, Leis et al. 2009) and suggest that other factors in addition to size are important in influencing swimming speed, such as larval condition (Leis \& McCormick 2002).

The $U_{\text {crit }}$ recorded for gilthead seabream larvae in the current study ranged from 1.7 to $19.3 \mathrm{~cm} \mathrm{~s}^{-1}$, which falls within the range of critical speeds found in other studied Sparidae larvae. A recent study by Koumoundouros et al. (2009) also examined the ontogeny of the $U_{\text {crit }}$ of pre-metamorphic (13.7 to $18.7 \mathrm{~mm}$ total length, TL) Sparus aurata larvae at different temperatures. At $20^{\circ} \mathrm{C}$, a temperature similar to the one used in the present study, average $U_{\text {crit }}$ of larvae was $10 \mathrm{~cm} \mathrm{~s}^{-1}$. Pattrick \& Strydom (2009) examined $U_{\text {crit }}$ and endurance of late-stage wild larvae of 2 other temperate Sparidae, Diplodus capensis and Sarpa salpa, and reported maximum $U_{\text {crit }}$ values of 35 and $33 \mathrm{~cm} \mathrm{~s}^{-1}$, respectively. Clark et al. (2005) studied the ontogeny of $U_{\text {crit }}$ of 2 warm-temperate Sparidae, Acanthopagrus australis and Pagrus auratus, over a size range similar to that used in the present work, and $U_{\text {crit }}$ speeds varied between 2 and $27 \mathrm{~cm} \mathrm{~s}^{-1}$.

Critical swimming speed did not differ between fed and unfed treatments, suggesting that the starvation period used ( $3 \mathrm{~d}$ ) is not sufficent to induce changes at the level of maximum attained speed of pre-settlement Sparus aurata larvae. The greatest impact of starvation on performance was seen in the endurance experiment: fed larvae swam twice as long as unfed larvae, with an average of $42.2 \mathrm{~h}$ and $19.7 \mathrm{~km}$, at $12 \mathrm{~cm} \mathrm{~s}^{-1}$. During swimming trials, lipids, carbohydrates and pro- teins are all used (Stobutzki 1997). Larvae that were fed ad libitum prior to the experiment clearly had more energy reserves than the ones that were starved for a $2 \mathrm{~d}$ period. These results suggest that reserves of unfed larvae were depleted faster than reserves of fed larvae and indicate that endurance is less limited by fatigue than by energy supplies. Other studies support this evidence. For example, Fisher \& Bellwood (2001) examined the effect of food on the sustained swimming ability of late-stage Amphiprion melanopus at $7 \mathrm{~cm} \mathrm{~s}^{-1}$ and reported an increased swimming distance from around 6.9 to $12.2 \mathrm{~km}$ when feeding larvae during the trial. Leis \& Clark (2005) also found that swimming endurance of late-stage larvae of 6 pomacentrid species was greatly increased by feeding; fed larvae were able to swim at least twice as long as unfed larvae.

The mean endurance results found are higher than values reported for settlement-stage larvae of other Sparidae: Pagrus auratus, $9.9 \mathrm{~km}$ at a speed of $10 \mathrm{~cm} \mathrm{~s}^{-1}$ (Clark et al. 2005) and Sarpa salpa and Diplodus capensis, 8 and $6 \mathrm{~km}$, respectively, at a speed of $18 \mathrm{~cm} \mathrm{~s}^{-1}$ (Pattrick \& Strydom 2009). These differences might be related to the speed chosen for the endurance experiments, but can also be attributed to the ontogenetic stage itself.

The lack of food deprivation effects on short-term swimming behaviours, such as $U_{\text {crit, }}$ has been reported in other studies. Laurence (1972) studied sustained swimming abilities and activity level of fed and starved largemouth bass Micropterus salmoides larvae at $19^{\circ} \mathrm{C}$ and found that differences in swimming activity were only notable after a period of $4 \mathrm{~d}$ of starvation. Similarly, Yin \& Blaxter (1987) reported decreased responsiveness and escape speed for starved herring, cod and flounder, reared at 9 to $10^{\circ} \mathrm{C}$, but the effects of starvation were not evident until larvae had been starved for several days. Chick \& Van den Avyle (2000) observed a similar pattern when examining the effects of feeding ration on the routine swimming speed of larval striped bass Morone saxatilis. More recently, Skajaa \& Browman (2007) concluded that escape responses in food-deprived cod larvae Gadus morhua were not, in general, affected by $3 \mathrm{~d}$ of food deprivation at $10^{\circ} \mathrm{C}$. These studies support the evidence that short-term swimming behaviours are conserved and even prioritised in food-deprivation scenarios. On the contrary, long-term performance, such as endurance swimming, is affected by short periods of starvation, which suggests that, in terms of dispersal potential (for which endurance swimming is critical), starving larvae may not succeed.

The RNA/DNA analysis confirmed differences in nutritional status between groups, but only after a $3 \mathrm{~d}$ period of food deprivation, which seems to indicate that this is the minimum starvation period necessary to 
induce changes in the RNA/DNA ratio for this species in these conditions. The RNA/DNA ratio has been shown to respond to changes in feeding conditions and growth in periods as short as 1 to $3 \mathrm{~d}$ in a variety of fish species (Clemmesen 1994, Rooker \& Holt 1996) and is a reliable growth rate estimator, which has been applied in numerous field assessments (Buckley et al. 1999, Gwak \& Tanaka 2001, Chícharo et al. 2003). Therefore, one might expect that a condition-related effect on behaviour might have been apparent if the larvae had been food-deprived for a longer period.

Grorud-Colvert \& Sponaugle (2006) studied the influence of condition on behaviour and survival potential of newly settled bluehead wrasse Thalassoma bifasciatum and reported that recruits fed for $1 \mathrm{wk}$ grew faster, had a greater Fulton's condition factor, swam faster and avoided simulated predators at faster speeds than recruits starved for the same period. Similar results were found in the present study, as fed larvae had higher Fulton's $K$ and higher endurance performance when compared to larvae deprived of food. A link between starvation, condition and behaviour is thus evident in these studies, although other possible explanatory factors exist, such as a change in the way larvae allocate energy for growth and swimming, but this is beyond the scope of the present study. Future work may supply further evidence in this regard.

The possible use of condition indices (RNA/DNA ratio and Fulton's $K$ ) as a proxy for swimming performance was also investigated. The results show that the RNA/DNA ratio is positively correlated with $U_{\text {crit, }}$ which indicates that larvae with higher condition are capable of attaining higher $U_{\text {crit }}$. Moreover, the measured morphometric index, Fulton's $K$, was highly correlated with endurance abilities. Despite this high correlation, care should be taken when extrapolating the attributes of laboratory-reared larvae to ocean-caught larvae (Ferron \& Leggett 1994). Larvae reared in the laboratory are usually fatter, exhibit less shrinkage, have less histological variation, less RNA and DNA relative to length (Ferron \& Leggett 1994) and may require prey concentrations 2 to 3 orders of magnitude greater than larvae in the field to survive (Suthers 1998). The mean $( \pm$ SD) RNA/DNA ratio in the present study was $3.31 \pm 2.28$ for fed larvae and $2.21 \pm 1.71$ for unfed larvae; the mean $( \pm \mathrm{SD})$ Fulton's $K$ was $0.28 \pm 0.13$ for fed larvae and $0.24 \pm 0.20$ for unfed larvae. The critical value of condition indices for survival is species specific, and, to our knowledge, no reference studies presently exist on the RNA/DNA ratio or Fulton's $K$ of wild-caught Sparus aurata larvae or any other sparid that could be used for comparison. Nevertheless, unpublished data on the nucleic acid content of wild-caught sparid larvae (Diplodus sp., M. A. Chícharo unpubl.) seem to be comparable to the values reported in the present study for fed larvae. Diplodus sp. larvae with a mean \pm SD size of $11.7 \pm 0.68 \mathrm{~mm}$ had a mean $\pm \mathrm{SD}$ RNA/DNA ratio of $3.8 \pm 1.04$ and a mean \pm SD Fulton's $K$ of $0.17 \pm 0.05$ ) (M. A. Chícharo unpubl.).

\section{CONCLUSIONS}

Effects of starvation on pre-settlement gilthead seabream Sparus aurata larvae were minimal or absent for short-term measurements of swimming performance $\left(U_{\text {crit }}\right)$, although other metabolic changes related to food deprivation were detected (as indicated by the changes in RNA/DNA ratios). On the contrary, the effects of starvation on endurance were significant. These results suggest that larvae may be capable of performing escape and foraging behaviours even in poor nutritional condition (activities in which critical speeds are involved), but sub-lethal effects of starvation may affect dispersal potential by greatly reducing endurance swimming, hence, compromising subsequent survival and recruitment to the adult population.

Acknowledgements. The authors thank T. Baptista and the fishery hatchery TIMAR for providing Sparus aurata larvae, J. Reis for support and facilities during the rearing period, and T. Muha for photographing larvae. Thanks are also due to the editor and 4 anonymous reviewers for very constructive comments and suggestions on the manuscript. This work was supported by a PhD grant to A.M.F. (SFRH/BD/21742/2005) and through the Pluriannual Program (R \& D Unit 331/94), financed by Fundação para a Ciência e a Tecnologia.

\section{LITERATURE CITED}

Almany GR, Webster MS (2005) The predation gauntlet: early post-settlement mortality in reef fishes. Coral Reefs 25: $19-22$

Armsworth PR (2001) Directed motion in the sea: efficient swimming by reef fish larvae. J Theor Biol 210:81-91

Bailey KM, Houde ED (1989) Predation on eggs and larvae of marine fishes and the recruitment problem. Adv Mar Biol 25:1-83

> Bentle LA, Dutta S, Metcoff J (1981) The sequential enzymatic determination of DNA and RNA. Anal Biochem 116: $5-16$

Bergenius MA, Meekan MG, Robertson DR, McCormick MI (2002) Larval growth predicts the recruitment success of a coral reef fish. Oecologia 131:521-525

Blaxter JHS, Ehrlich KF (1974) Changes in behaviour during starvation of herring and plaice larvae. In: Blaxter JHS (ed) The early life history of fish. Springer-Verlag, Berlin, p 575-588

Brett JR (1964) The respiratory metabolism and swimming performance of young sockeye salmon. J Fish Res Board Can 21:1183-1226

Buckley L, Caldarone E, Ong TL (1999) RNA-DNA ratio and other nucleic acid-based indicators for growth and condition of marine fishes. Hydrobiologia 401:265-277

Bulow FJ (1970) RNA-DNA ratios as indicators of recent growth rates of a fish. J Fish Res Board Can 27:2343-2349 
Caldarone EM, Wagner M, Onge-Burnes JS, Buckley LJ (2001) Protocol and guide for estimating nucleic acids in larval fish using a fluorescence microplate reader. Ref Doc 01-11, Northeast Fisheries Science Center, Woods Hole, MA

Caldarone EM, Onge-Burns JM, Buckley LJ (2003) Relationship of RNA/DNA ratio and temperature to growth in larvae of Atlantic cod Gadus morhua. Mar Ecol Prog Ser 262: 229-240

Caldarone EM, Clemmesen CM, Berdalet E, Miller T and others (2006) Inter-calibration of four spectro-fluorometric protocols for measuring RNA/DNA ratios in larval and juvenile fish. Limnol Oceanogr Methods 4:153-163

> Chícharo MA, Esteves E, Santos AMP, dos Santos A, Peliz A, Re P (2003) Are sardine larvae caught off northern Portugal in winter starving? An approach examining nutritional conditions. Mar Ecol Prog Ser 257:303-309

Chick JH, Van den Avyle MJ (2000) Effects of feeding ration on larval swimming speed and responsiveness to predator attacks: implications for cohort survival. Can J Fish Aquat Sci 57:106-115

Clark DL, Leis JM, Hay AC, Trnski T (2005) Swimming ontogeny of larvae of four temperate marine fishes. Mar Ecol Prog Ser 292:287-300

> Clemmesen C (1994) The effect of food availability, age or size on the RNA/DNA ratio of individually measured herring larvae: laboratory calibration. Mar Biol 118:377-382

Clemmesen C, Sanchez R, Wongtschowski C (1997) A regional comparison of the nutritional condition of SW Atlantic anchovy larvae, Engraulis anchoita, based on RNA/DNA contents. Arch Fish Mar Res 45:17-43

Ehrlich KF, Blaxter JHS, Pemberton R (1976) Morphological and histological changes during the growth and starvation of herring and plaice larvae. Mar Biol 35:105-118

Esteves E, Chícharo MA, Pina T, Coelho ML, Andrade JP (2000) Comparison of RNA/DNA ratios obtained with two methods for nucleic acid quantification in gobiid larvae. J Exp Mar Biol Ecol 243:81-94

> Faria A, Ojanguren A, Fuiman L, Gonçalves E (2009) Ontogeny of critical swimming speed of wild-caught and laboratory-reared larvae of red drum (Scieanops ocellatus). Mar Ecol Prog Ser 384:221-230

Ferron A, Leggett WC (1994) An appraisal of condition measures for marine fish larvae. Adv Mar Biol 30:217-286

Fisher R, Bellwood DR (2001) Effects of feeding on the sustained swimming abilities of late-stage larval Amphiprion melanopus. Coral Reefs 20:151-154

Fisher R, Wilson SK (2004) Maximum sustainable swimming speeds of late-stage larvae of nine species of reef fishes. J Exp Mar Biol Ecol 312:171-186

Fisher R, Bellwood DR, Job SD (2000) Development of swimming abilities in reef fish larvae. Mar Ecol Prog Ser 202: 163-173

Fuiman LA, Ottey DR (1993) Temperature effects on spontaneous behaviour of larval and juvenile red drum $\mathrm{SCi}_{\mathrm{C}}$ aenops ocellatus, and implications for foraging. Fish Bull 91:23-35

Grorud-Colvert K, Sponaugle S (2006) Influence of condition on behaviour and survival potential of a newly settled coral reef fish, the bluehead wrasse Thalassoma bifasciatum. Mar Ecol Prog Ser 327:279-288

Gwak WS, Tanaka M (2001) Developmental changes in RNA/DNA ratios of fed and starved laboratory-reared Japanese flounder larvae and juveniles, and its application to assessment of nutritional condition for wild fish. J Fish Biol 59:902-915

Kamler E, Szlamiñska M, Przybyl A, Barska B, Jakubas M,
Kuczyñski M, Raciborsku K (1990) Developmental response of carp, Cyprinus carpio, larvae fed different foods or starved. Environ Biol Fishes 29:303-313

> Koumoundouros G, Ashton C, Xenikoudakis G, Giopanou I, Georgakopoulou E, Stickland N (2009) Ontogenetic differentiation of swimming performance in gilthead seabream (Sparus aurata, Linnaeus 1758) during metamorphosis. J Exp Mar Biol Ecol 370:75-81

> Laurence G (1972) Comparative swimming abilities of fed and starved larval largemouth bass (Micropterus salmoides). J Fish Biol 4:73-78

Leis JM (2006) Are larvae of demersal fishes plankton or nekton? Adv Mar Biol 51:57-141

Leis JM, Clark DL (2005) Feeding greatly enhances swimming endurance of settlement-stage reef-fish larvae of damselfishes (Pomacentridae). Ichthyol Res 52:185-188

Leis JM, McCormick MI (2002) The biology, behaviour and ecology of the pelagic, larval stage of coral-reef fishes. In: Sale PF (ed) Coral reef fishes: new insights into their ecology. Academic Press, San Diego, CA, p 171-199

- Leis JM, Piola RF, Hay AC, Wen C, Kan KP (2009) Ontogeny of behaviour relevant to dispersal and connectivity in the larvae of two non-reef demersal, tropical fish species. Mar Freshw Res 60:211-223

McCormick MI, Hoey AS (2004) Larval growth history determines juvenile growth and survival in a tropical marine fish. Oikos 106:225-242

Miller TJ, Crowder LB, Rice JA, Marschall EA (1988) Larval size and recruitment mechanisms in fishes: toward a conceptual framework. Can J Fish Aquat Sci 45:1657-1688

Munk P (1995) Foraging behaviour of larval cod (Gadus morhua) influenced by prey density and hunger. Mar Biol 122:205-212

> Neilson JD, Perry RI, Valerio PF, Waiwood KG (1986) Condition of Atlantic cod Gadus morhua larvae after the transition to exogenous feeding: morphometrics, buoyancy and predator avoidance. Mar Ecol Prog Ser 32:229-235

> Pattrick P, Strydom NA (2009) Swimming abilities of wildcaught, late-stage larvae of Diplodus capensis and Sarpa salpa (Pisces: Sparidae) from temperate South Africa. Estuar Coast Shelf Sci 85:547-554

Plaut I (2001) Critical swimming speed: its ecological relevance. Comp Biochem Physiol A 131:41-50

Reidy SP, Kerr SR, Nelson JA (2000) Aerobic and anaerobic swimming performance of individual Atlantic cod. J Exp Biol 203:347-357

Ricker WE (1975) Computation and interpretation of biological statistics of fish populations. Bull Fish Res Board Can 191:1-382

> Rooker JR, Holt GJ (1996) Application of RNA/DNA ratios to evaluate the condition and growth of larval and juvenile red drum (Sciaenops ocellatus). Mar Freshw Res 47:283-290

> Ross RM, Johnson JH, Bennett RM, Dropkin DS (1996) Behavioral changes associated with suboptimal prey densities for larval American shad. Ecol Freshwat Fish 5:163-168

Searcy S, Sponaugle S (2001) Selective mortality during the larval-juvenile transition in two coral reef fishes. Ecology 82:2452-2470

Skajaa K, Browman HI (2007) The escape response of fooddeprived cod larvae (Gadus morhua L.). J Exp Mar Biol Ecol 353:135-144

Skajaa K, Fernf A, Folkvord A (2004) Ontogenetic- and condition-related effects of starvation on responsiveness in herring larvae (Clupea harengus L.) during repeated attacks by a model predator. J Exp Mar Biol Ecol 312:253-269

> Sponaugle S, Grorud-Colvert K, Pinkard D (2006) Temperature-mediated variation in early life history traits and 
recruitment success of the coral reef fish Thalassoma bifasciatum in the Florida Keys. Mar Ecol Prog Ser 308:1-15

Stobutzki IC (1997) Energetic cost of sustained swimming in the late pelagic stages of reef fishes. Mar Ecol Prog Ser 152:249-259

Stobutzki IC (1998) Interspecific variation in sustained swimming ability of late pelagic stage reef fish from two families (Pomacentridae and Chaetodontidae). Coral Reefs 17: 111-119

Stobutzki IC, Bellwood DR (1994) An analysis of the sustained swimming abilities of pre- and post-settlement coral reef fishes. J Exp Mar Biol Ecol 175:275-286

Stobutzki IC, Bellwood DR (1997) Sustained swimming abilities of the late pelagic stages of coral reef fishes. Mar Ecol Prog Ser 149:35-41

Editorial responsibility: Roderick Finn,

Bergen, Norway
Suthers IM (1998) Bigger? Fatter? Or is faster growth better? Considerations on condition in larval and juvenile coralreef fish. Aust J Ecol 23:265-273

Wagner MM, Durbin EG, Buckley LJ (1998) RNA/DNA ratios as indicators of nutritional condition in the copepod Calanus finmarchicus. Mar Ecol Prog Ser 162:173-181

Yin MC, Blaxter JHS (1986) Morphological changes during growth and starvation of larval cod (Gadus morhua L.) and flounder (Platichthys flesus L.). J Exp Mar Biol Ecol 104: 215-228

Yin MC, Blaxter JHS (1987) Escape speeds of marine fish larvae during early development and starvation. Mar Biol 96: $459-468$

Zar J (1999) Biostatistical analysis. Prentice Hall Press, Englewood Cliffs, NJ

Submitted: April 26, 2010; Accepted: April 2, 2011

Proofs received from author(s): June 7, 2011 